\title{
The dynamics of microbial partnerships in the coral Isopora palifera
}

\author{
Chung-Pin Chen ${ }^{1}$, Ching-Hung Tseng ${ }^{1,2}$, Chaolun A Chen ${ }^{1}$ and Sen-Lin Tang ${ }^{1}$ \\ ${ }^{1}$ Biodiversity Research Center, Academia Sinica, Taipei, Taiwan and ${ }^{2}$ Bioinformatics Program, \\ Taiwan International Graduate Program, Academia Sinica, Taipei, Taiwan
}

\begin{abstract}
Both bacteria and algal symbionts (genus Symbiodinium), the two major microbial partners in the coral holobiont, respond to fluctuations in the environment, according to current reports; however, little evidence yet indicates that both populations have any direct interaction with each other in seasonal fluctuation. In this study, we present field observations of a compositional change in bacteria and Symbiodinium in the coral Isopora palifera in three separate coral colonies following monthly sampling from February to November in 2008. Using massively parallel pyrosequencing, over 200000 bacterial V6 sequences were classified to build the bacterial community profile; in addition, the relative composition and quantity of Symbiodinium clades $C$ and $D$ were determined by real-time PCR. The results showed that coral-associated bacterial and Symbiodinium communities were highly dynamic and dissimilar among the tagged coral colonies, suggesting that the effect of host specificity was insignificant. The coral-associated bacterial community was more diverse (Shannon index up to 6.71) than previous estimates in other corals and showed rapid seasonal changes. The population ratios between clade $C$ and D groups of Symbiodinium varied in the tagged coral colonies through the different seasons; clade $D$ dominated in most of the samples. Although significant association between bacteria and symbiont was not detected, this study presents a more detailed picture of changes in these two major microbial associates of the coral at the same time, using the latest molecular approaches.
\end{abstract}

The ISME Journal (2011) 5, 728-740; doi:10.1038/ismej.2010.151; published online 21 October 2010

Subject Category: microbial ecology and functional diversity of natural habitats

Keywords: coral; bacterial community; Symbiodinium; metagenomics; tag pyrosequencing

\section{Introduction}

Corals generally associate with a variety of microorganisms, including algae, bacteria, archaea and viruses (Knowlton and Rohwer, 2003; Wegley et al., 2007; Marhaver et al., 2008). Among these associated partners, the most well known are the algal symbionts (genus Symbiodinium) and various bacteria. Symbiodinium are photosynthetic algal symbionts providing energy for corals (Baker, 2003). Based on their ribosomal DNA sequences, Symbiodinium can be categorized into eight distinct phylogenetic clades (A-H), five of which (A-D, F) are associated with corals (Baker, 2003). Symbiodinium are geographically specific; the clades $\mathrm{C}$ and $\mathrm{D}$ are dominant in the corals dwelling in western Pacific Ocean, whereas other types are detected in other oceans, for example, the Caribbean Sea (Baker, 2003). Symbiodinium are functionally diverse and, typically, display variations in tolerance against

Correspondence: S-L Tang, Biodiversity Research Center, Academia Sinica, 128 Academia Road, Section 2, Nankang, Taipei 11529, Taiwan.

E-mail: sltang@gate.sinica.edu.tw

Received 4 March 2010; revised 29 July 2010; accepted 18 August 2010; published online 21 October 2010 high temperature and irradiance (Baker, 2003; Stat et al., 2008; Mieog et al., 2009; Takahashi et al., 2009). For instance, Symbiodinium clade D is more heat tolerant and is thus found more often in corals subject to conditions of higher temperature or irradiance (Baker, 2001; Rowen, 2004). Because of differences in the physiological characteristics of each type, the population composition of Symbiodinium in a coral may change under different environmental conditions, such as season (Chen et al., 2005), latitude (LaJeunesse et al., 2004) and depth (Toller et al., 2001; Frade et al., 2008).

Coral-associated bacteria are highly diverse (Rohwer et al., 2002) and their population compositions are affected by environmental factors such as geographic differences (Hong et al., 2009; Littman et al., 2009), seasonal changes (Koren and Rosenberg, 2006; Hong et al., 2009), coastal pollution (Klaus et al., 2007) and nutrient status (Garren et al., 2009). They potentially have functions relating to coral health, nutrition and disease (Reshef et al., 2006; Rosenberg et al., 2007; Wegley et al., 2007), but their definitive role remains unclear. Many questions also remain about the dynamics of coral-associated bacteria. What factors affect their composition? What are the ecological implications of their compositions and dynamics? 
To determine the composition of a coral bacterial population, one of the most common methods has been construction of a 16S rRNA gene clone library (Amann et al., 1995; Rohwer et al., 2002; Lampert et al., 2008; Hong et al., 2009; Reis et al., 2009). Surveying the range of bacterial 16S rRNA gene sequences from such a library provides more detailed taxonomic information of bacterial community than other older methods. This culture-independent method has circumvented the difficulty of unculturable bacteria detection and offers considerable understanding of bacterial biodiversity and ecology (Amann et al., 1995; Rohwer et al., 2002). However, the clone library method has long been limited in the number of colonies picked, mainly because of cost considerations (Rohwer et al., 2002; Lampert et al., 2008; Hong et al., 2009; Reis et al., 2009). As a result, practical application of this method is unfeasible to present the profile of the very diverse bacterial communities found in most environmental samples. To define such a community more precisely, large survey size is crucial. For example, picking 1000 $16 \mathrm{~S}$ rRNA sequences from a clone library would be minimally sufficient to define a coastal bacterial community (Acinas et al., 2004). Similarly, with the current limitations on sampling number, studies of coral-associated bacterial communities with extensive temporal or spatial scales would be impossible.

Massively parallel pyrosequencing (MPP) offers a high-throughput and cost-effective system for survey of bacterial communities by revealing the sequence of a hypervariable region of the 16S rRNA gene (Sogin et al., 2006). Compared with the fulllength rRNA gene sequence, the information from the hypervariable region sequence provides nearly equivalent taxonomic data (Huse et al., 2008). This robust method has recently been employed to analyze the biodiversity of complex bacterial communities in different habitats such as the human gut (Huse et al., 2008), hydrothermal vents (Huber et al., 2007) and soil (Roesch et al., 2007). Moreover, modifying the PCR primers with unique sequences in the sequencing reaction makes the method more economical and practical. DNA amplification with different unique-sequence-designed primers for each sample from different sources allows sequencing of all the amplicons from multiple sources in a single reaction run and still offers a sufficient number of sequences for the unbiased analysis of a bacterial community. The sequences in each sample can be simply sorted according to unique sequences of the primers (Binladen et al., 2007; Andersson et al., 2010; Barriuso et al., 2010).

In this study, we adopted the MPP technique and a newly improved quantitative PCR method to study the dynamics of bacterial and symbiotic algal communities in Isopora palifera with a monthly sampling survey from February to November in 2008. These rich data sets have provided much detail about the dynamics of these two microbial communities, bacteria and Symbiodinium.

\section{Materials and methods}

The experimental methods used to analyze the composition of microorganisms in coral I. palifera are illustrated in Supplementary Figure S1, which presents a flowchart of the procedure from bench work to bioinformatics analysis.

\section{Study site and sampling}

Coral samples and seawater samples were collected from Tan-Tzei Bay $\left(21^{\circ} 57^{\prime} \mathrm{N}, 120^{\circ} 46^{\prime} \mathrm{E}\right)$, Ken-Ting National Park, located in Heng-Chun Township at the southern tip of Taiwan. Three colonies of the coral I. palifera, at 2 to $3 \mathrm{~m}$ depth, were tagged as 351,352 and 353. I. palifera is a plate form in this area (Supplementary Figure S6). Near the tagged coral colonies, we deposited a thermograph to record water temperature.

All tagged colonies were sampled near-monthly for the 7 months of February (winter), April (spring), May (spring), June (summer), July (summer), August (summer) and November (winter) in 2008. Coral fragments $(\sim 2 \times 2 \mathrm{~cm})$ were collected with hammer and chisel. In addition, $1000 \mathrm{ml}$ sea water was collected from the area near the tagged colonies.

Coral samples were washed twice with sterile synthetic sea water and then sprayed with TE buffer (10 mM Tris-HCl, pH 7.5, $1 \mathrm{mM}$ EDTA, pH 8.0) to collect the tissue, using an airbrush. Coral tissue was stored in liquid nitrogen until DNA extraction. Seawater samples were filtered through membrane paper (pore size $0.2 \mu \mathrm{m}$; Adventec, Tokyo, Japan) to collect the microbial particles. After filtering, the paper was kept at $-20^{\circ} \mathrm{C}$ until DNA extraction.

\section{DNA extraction}

The coral tissues were recovered from the TE buffer by centrifugation; after discarding the supernatant, tissue pellets were then resuspended with $1 \mathrm{ml} \mathrm{TE}$ buffer, and homogenized in a mortar and pestle with liquid nitrogen. The homogenized solution was transferred to a clean tube, and total DNAs were extracted with a PowerSoil DNA Isolation Kit (MoBio, Solana Beach, CA, USA) according to the manufacturer's instructions. To isolate the total DNAs of seawater samples, the filter membrane paper with adsorbed microbial sample was cut into smaller pieces and placed into a clean tube, and the total DNA again extracted using a PowerSoil DNA Isolation Kit (MoBio). Finally, the DNA was resuspended in $150 \mu \mathrm{l}$ sterile Milli-Q water, aliquoted into PCR microtubes (each tube $10 \mu \mathrm{l}$ ) and stored at $-80^{\circ} \mathrm{C}$.

PCR of bacterial V6 hypervariable region of the $16 S$ ribosomal RNA gene and DNA tagging PCR

For amplification of the bacterial V6 hypervariable region of the $16 \mathrm{~S}$ ribosomal RNA gene, two bacterial universal primers were used: 967F, 5'-CAACGCGA AGAACCTTACC-3' ${ }^{\prime}$ and 1046R, 5'-CGACAGCCATG 
CANCACCT-3' (Sogin et al., 2006) with the following PCR conditions: an initial step of $94{ }^{\circ} \mathrm{C}$ for $3 \mathrm{~min}, 30$ cycles of $94^{\circ} \mathrm{C}$ for $30 \mathrm{~s}, 57^{\circ} \mathrm{C}$ for $10 \mathrm{~s}$ and $72^{\circ} \mathrm{C}$ for $30 \mathrm{~s}$, followed by a final step of $72{ }^{\circ} \mathrm{C}$ for $2 \mathrm{~min}$. The amplification mixture contained $0.5 \mu \mathrm{l}$ of $5 \mathrm{U}$ TaKaRa $E_{X}$ Taq HS (Takara Bio, Otsu, Japan), $5 \mu \mathrm{l}$ of $10 \times E_{X}$ Taq buffer, $4 \mu \mathrm{l}$ of $2.5 \mathrm{mM}$ deoxynucleotide triphosphate mixture, $1 \mu \mathrm{l}$ of each primer $(10 \mu \mathrm{M})$ and $5 \mu \mathrm{l}$ (10-20 ng) template DNA in a volume of $50 \mu \mathrm{l}$. The PCR amplicons of the V6 region were checked by $15 \%$ native polyacrylamide gel electrophoresis with TAE buffer. The expected DNA band ( 100 bp) was cut and DNA extracted by electroelution (Sambrook and Russell, 2001). The quality of the purified product was assayed using a NanoDrop spectrophotometer (Thermo Scientific, Vantaa, Finland).

DNA tagging PCR (DT-PCR) was used to add unique tags to each of the PCR products isolated from different samples (Supplementary Figure S2a). Each tag primer was designed with four overhanging nucleotides at the $5^{\prime}$ end of the $967 \mathrm{~F}$ and 1046R primers. The arrangements of the four nucleotides ensured 256 different kinds of unique tags. In this study, 28 unique tags were used for DT-PCR.

In DT-PCR, the PCR products from individual sample were extended with different unique-tagged primer sets by low-cycle PCR under the following conditions: an initial $94^{\circ} \mathrm{C}$ for $3 \mathrm{~min}$, then 5 cycles of $94{ }^{\circ} \mathrm{C}$ for $30 \mathrm{~s}, 57^{\circ} \mathrm{C}$ for $10 \mathrm{~s}$ and $72^{\circ} \mathrm{C}$ for $30 \mathrm{~s}$, followed by $72{ }^{\circ} \mathrm{C}$ for $2 \mathrm{~min}$. The DT-PCR mixture contained $0.5 \mu \mathrm{l}$ of $5 \mathrm{U}$ TaKaRa Ex Taq HS, $5 \mu \mathrm{l}$ of $10 \times$ Ex Taq Buffer, $4 \mu \mathrm{l}$ of $2.5 \mathrm{~mm}$ deoxynucleotide triphosphates, $1 \mu \mathrm{l}$ of each primer $(10 \mu \mathrm{M})$ and $20 \mu \mathrm{l}$ (50-100 ng) V6 amplicon in a volume of $50 \mu \mathrm{l}$. To confirm the success of the tagging reaction, we checked the PCR products after DT-PCR using nondenatured polyacrylamide gel electrophoresis on $15 \%$ gels run at $100 \mathrm{~V}$ for $6 \mathrm{~h}$ and stained with SYBR-Gold (Invitrogen, Carlsbad, CA, USA). In comparison with the V6 PCR products, the tagged V6 DNA would shift to a higher position in the gel because of their larger molecular mass (Supplementary Figure S2b). Once the tagging reaction was successful, we then purified the tagged amplicon DNAs using PCR Purification Kits (Qiagen, Valencia, CA, USA). The qualities and concentrations of the purified tagged DNA samples were determined using NanoDrop spectrophotometer (Thermo Scientific).

\section{Parallel pyrosequencing}

Pooled $200 \mathrm{ng}$ lots of each tagged V6 DNA samples (28 samples in total) were used for parallel pyrosequencing on a Roche 454 Genome Sequencer FLX System at Mission Biotech (Taipei, Taiwan). Ambiguous reads were trimmed off if the sequences had mismatched sequences to the forward and reverse primers or the sequences were shorter than 75 bases. A total of 205082 sequences were generated and sorted according to unique tags using an in-house sorting tool (http://tanglab.csie.org/ tanglab/proj1/).
Determination of Symbiodinium population by PCR length heteroplasmy (PCR-LH) analysis and quantitative PCR

For PCR heteroplasmy analysis, we designed new primers specific for clades C and D of algal symbionts: SymITS2-F (5'-TATGTYTGCTTCAGTGC TTA-3'), Clade-C-ITS2-R (5'-AATTAACAAGCCATT GGC-3'), and Clade-D-ITS2-R (5'-ACTCAGCAAGCC ATGGGC-3') according to the internal transcribed spacer 2 (ITS2) region sequences of Symbiodinium from the NCBI (National Center for Biotechnology Information) database (Supplementary Figure S3). The PCR mixture contained $0.5 \mu \mathrm{l}$ of $5 \mathrm{U}$ TaKaRa $E_{X}$ Taq HS, $5 \mu \mathrm{l}$ of $10 \times E_{X}$ Taq Buffer, $4 \mu \mathrm{l}$ of $2.5 \mathrm{mM}$ deoxynucleotide triphosphate mixture, $1 \mu \mathrm{l}$ of $10 \mu \mathrm{M}$ SymITS2-F, $0.5 \mu \mathrm{l}$ of $10 \mu \mathrm{M}$ Clade-C-ITS2-R, $0.5 \mu \mathrm{l}$ of $10 \mu \mathrm{M}$ Clade-D-ITS2-R and 2-5 ng template DNA in a total volume of $50 \mu \mathrm{l}$. The amplified condition had the following steps: an initial $94^{\circ} \mathrm{C}$ for $3 \mathrm{~min}$, then 35 cycles of $94{ }^{\circ} \mathrm{C}$ for $30 \mathrm{~s}, 50{ }^{\circ} \mathrm{C}$ for $30 \mathrm{~s}$ and $72^{\circ} \mathrm{C}$ for $20 \mathrm{~s}$, and finally $72^{\circ} \mathrm{C}$ for $2 \mathrm{~min}$.

After the DNA of ITS2 partial region was amplified, $4 \mu \mathrm{l}$ of the PCR products of each sample was mixed with $4 \mu \mathrm{l}$ of $2 \times$ DNA loading dye $(0.05 \%$ bromophenol blue, $0.05 \%$ xylene cyanol, $20 \mathrm{mM}$ EDTA and 10\% glycerol), and analyzed by electrophoresis on $15 \%$ polyacrylamide gels with $7 \mathrm{M}$ urea. Gels were run at $85 \mathrm{~V}$ for $16 \mathrm{~h}$ in $0.5 \times$ Tris-borateEDTA (TBE) buffer ( $45 \mathrm{~mm}$ Tris-borate and $1 \mathrm{~mm}$ EDTA) at a constant temperature of $55^{\circ} \mathrm{C}$ and stained with SYBR-Gold. The relative intensities of each expected band (clades $C$ and D) were quantified using ImageQuant TL (Amersham Bioscience, GE Healthcare, Waukesha, WI, USA).

For the quantitative PCR analysis (Q-PCR), we designed two pairs of specific primers for the ITS1 partial region ( $\sim 100 \mathrm{bp})$ of Symbiodinium clades $\mathrm{C}$ and D according to the ITS1 region sequences of Symbiodinium from the NCBI database. Three primers were designed: QPCR ITS1-F (5'-TGCGGAA GGATCATTCGCAC-3') for both algal symbiont populations, and QPCR-SymITSC-R (5'-CCTCGAGTT CTGCCAGCAGAT- $3^{\prime}$ ) specific for clade $\mathrm{C}$ and QPCRSymITSD-R (5'-TGAACGCGCATCTCACCACTG-3') specific for clade D. To avoid pipette error, the total DNA of the coral sample was diluted ninefold before

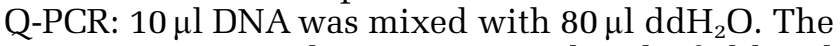
Q-PCR reaction solution contained $9 \mu$ l of diluted coral tissue total DNA, $0.2 \mu \mathrm{M}$ of QPCR ITS1-F (universal primer), $0.2 \mu \mathrm{M}$ of QPCR-SymITSC-R (for clade C) or QPCR-SymITSD-R (for clade D) and $1 \times$ SYBR Green PCR Master Mix (Applied Biosystems, Foster City, CA, USA) in a total volume of $20 \mu \mathrm{l}$. Q-PCR analysis was performed in an ABI 7300 Real-Time PCR System (Applied Biosystems) under the following conditions: $50^{\circ} \mathrm{C}$ for $2 \mathrm{~min}, 95^{\circ} \mathrm{C}$ for $10 \mathrm{~min}$; 40 cycles of $95^{\circ} \mathrm{C}$ for $10 \mathrm{~s}$ and $62^{\circ} \mathrm{C}$ for $27 \mathrm{~s}$, followed by $95^{\circ} \mathrm{C}$ for $15 \mathrm{~s}, 60^{\circ} \mathrm{C}$ for $1 \mathrm{~min}, 95^{\circ} \mathrm{C}$ for $15 \mathrm{~s}$, and $60^{\circ} \mathrm{C}$ for $15 \mathrm{~s}$ for the dissociation step. A standard curve was constructed with a series dilution of template DNA from ITS PCR products of known 
concentration. The data were analyzed using ABI 7300 System SDS Software (Applied Biosystems).

\section{Diversity indices and OTU definition}

We aligned sequences from individual samples using MUSCLE software (http://www.drive5.com/muscle/) and calculated distances matrices based on the JukeCantor model. The distance matrices were then used as input to the DOTUR software (Schloss and Handelsman, 2005) to define the operational taxonomic units (OTUs) with a $3 \%$ cutoff value and to estimate the Shannon-Weaver diversity index, Chao1 estimator and Simpson index, and to construct rarefaction curves. Calculations of evenness and richness were also based on the number of OTUs.

\section{Taxonomic identification of bacterial V6 sequences}

We identified the taxonomic information of the V6 sequences (205082 reads) using Ribosomal Data Project (RDP) SeqMatch software (http://rdp.cme. msu.edu/seqmatch/seqmatch_intro.jsp) with 5 KNN match. Those sequences identified as 'unclassified bacteria' by SeqMatch were reconfirmed using an in-house program, Greedy Fetching (GF; C-H Tseng et al., unpublished), based on the BLASTn results to assign taxonomy of V6 reads with a similarity threshold of 0.7 and the approved hits were all at lease with 0.91 alignment identity, which is enough to define taxonomy at class level. GF provided a more extensive calculation in sequence similarity searching and enabled us to detect missing information that could not be determined using SeqMatch. The outcome of GF was merged with the results of the RDP SeqMatch analysis.

To analyze the dynamics of the coral-associated bacteria community in the different months, we examined 45314 unique groups from 205082 V6 sequences according to sequence similarity; any mismatch or inserted or deleted base between two V6 sequences was regarded as a different unique V6 sequence group. Through plotting and comparing these unique groups in the monthly samples, we were able to survey more detailed information of the compositional changes of the bacterial community. The unique sequence groups were classified taxonomically into different groups at the class level by SeqMatch and GF.

\section{Non-metric multidimensional scaling (nMDS) \\ ordination}

The relationships among samples were determined by the statistical method, nMDS ordination (Kenkel and Orlóci, 1986), using each different V6 sequence group as an OTU. To refine OTUs, we aligned these 45314 unique group sequences from all samples using the program MUSCLE (http://www.drive5. com/muscle/) and calculated distance matrices based on the Juke-Cantor model. These distance matrices were input to DOTUR software (Schloss and Handelsman, 2005) to define the OTUs with a
$3 \%$ cutoff value. This calculation estimated 11236 OTUs. Then, the relative percentages of each OTU in each sample were incorporated into a matrix to estimate a distance matrix (via City-Block distance) to present the nMDS profile using Primer 6 software (PRIMER-E, Lutton, Ivybridge, UK).

\section{Hierarchical cluster analysis}

Hierarchical cluster analysis was used to analyze the relationship between environmental factors (seawater temperature, sunlight intensity and rainfall), bacterial community and symbiotic algal population. We used the software Gene Cluster 3.0 (de Hoon et al., 2004) from http://www.falw.vu/ rhuik/cluster.htm to construct the clusters. The population ratio of each bacterial group was derived from the sequence data sets (classified by SeqMatch and GF at the class level), and the population proportion of the two symbiotic algal groups was determined according to the Q-PCR data sets. Data on sunlight intensity and rainfall were collected from the Central Weather Bureau of Taiwan in Heng-Chun Township, at the southern tip of Taiwan. In the hierarchical cluster analysis, the distance matrix was constructed with normalized data. To normalize the data, we deducted the raw value of each data point from the relevant mean value and then divided by the standard deviation. The cluster constructed was based on the distance matrix with the uncentered correlation distance and complete linkage, two options in Gene Cluster 3.0 (de Hoon et al., 2004). We then visualized the clustering map using Java Treeview software, downloaded from http://jtreeview.sourceforge.net/, with a contrast value of 1.5 to enhance readability.

\section{Results}

I. palifera-associated bacterial community and its diversity

Coral samples of three tagged I. palifera colonies were collected near-monthly in 2008 (from February to November) at Tan-Zi Bay in Ken-Ting National Park, Taiwan. The V6 hypervariable regions of bacterial 16S ribosomal RNA genes were surveyed to determine bacterial community composition of the monthly samples. After V6 DNA amplification by PCR with universal primers and DNA tagging (Supplementary Figure S2), we performed MPP to acquire sequence data.

The number of V6 sequences in each sample varied from 657 to 21091 (Table 1); however, the rarefaction curves (with a $3 \%$ cutoff value) of the samples showed that the sampling size (read number) was generally sufficient (Supplementary Figure S4).

I. palifera-associated bacterial communities were highly diverse (Table 1). Shannon's index ranged from 3.64 to 6.71 in the coral samples and from 3.85 to 6.32 in the sea water. Simpson's index in coral samples ranged from 0.009 to 0.069 and in sea water 
Table 1 Sequence information and diversity estimates as represented in V6 tags ${ }^{\mathrm{a}}$

\begin{tabular}{|c|c|c|c|c|c|c|c|}
\hline Index & $351-F e b$ & $351-A p r$ & 351-May & 351-Jun & 351-Jul & 351-Aug & 351-Nov \\
\hline$S^{\mathrm{b}}$ & 690 & 304 & 942 & 1623 & 778 & 863 & 554 \\
\hline$N^{\mathrm{c}}$ & 6724 & 1751 & 15696 & 19496 & 4757 & 9256 & 2359 \\
\hline Evenness $^{\mathrm{d}}$ & 0.71 & 0.80 & 0.73 & 0.87 & 0.76 & 0.81 & 0.84 \\
\hline Richness $^{\mathrm{e}}$ & 180.01 & 93.42 & 224.27 & 211.29 & 217.32 & 217.32 & 163.96 \\
\hline Shannon & 4.67 & 4.56 & 4.98 & 5.82 & 5.14 & 5.49 & 5.3 \\
\hline Chao 1 & $\begin{array}{c}959 \\
(887-1057)^{\mathrm{f}}\end{array}$ & $\begin{array}{c}427 \\
(381-501)^{\mathrm{f}}\end{array}$ & $\begin{array}{c}1073 \\
(1033-1131)^{\mathrm{f}}\end{array}$ & $\begin{array}{c}1966 \\
(1887-2069)^{\mathrm{f}}\end{array}$ & $\begin{array}{c}1179 \\
(1081-1309)^{\mathrm{f}}\end{array}$ & $\begin{array}{c}1085 \\
(1025-1166)^{\mathrm{f}}\end{array}$ & $\begin{array}{c}989 \\
(872-1149)^{\mathrm{f}}\end{array}$ \\
\hline Simpson & 0.026 & 0.029 & 0.031 & 0.017 & 0.028 & 0.009 & 0.012 \\
\hline Index & $352-\mathrm{Feb}$ & 352-Apr & 352-May & 352-Jun & 352-Jul & 352-Aug & $352-\mathrm{NoV}$ \\
\hline$S^{\mathrm{b}}$ & 392 & 654 & 1378 & 710 & 460 & 498 & 794 \\
\hline$N^{\mathrm{c}}$ & 2281 & 6396 & 17256 & 9523 & 4592 & 3296 & 4300 \\
\hline Evenness $^{\mathrm{d}}$ & 0.85 & 0.80 & 0.75 & 0.76 & 0.78 & 0.80 & 0.74 \\
\hline Richness $^{\mathrm{e}}$ & 116.43 & 171.58 & 325.00 & 178.20 & 125.34 & 141.27 & 218.25 \\
\hline Shannon & 5.1 & 5.20 & 5.44 & 5.02 & 4.79 & 4.97 & 4.96 \\
\hline \multirow[t]{2}{*}{ Chao 1} & 476 & 811 & 1701 & 764 & 598 & 643 & 1071 \\
\hline & $(444-526)^{\mathrm{f}}$ & $(763-880)$ & $(1625-1800)$ & $(743-800)$ & $(550-670)$ & $(597-711)$ & $(1003-1160)$ \\
\hline Simpson & 0.014 & 0.015 & 0.023 & 0.029 & 0.023 & 0.019 & 0.04 \\
\hline Index & $353-F e b$ & 353-Apr & 353-May & 353-Jun & 353-Jul & 353-Aug & 353-Nov \\
\hline$S^{\mathrm{b}}$ & 648 & 181 & 588 & 400 & 1360 & 1804 & 365 \\
\hline$N^{\mathrm{c}}$ & 6048 & 1567 & 4791 & 2640 & 10867 & 7785 & 4545 \\
\hline Evenness $^{\mathrm{d}}$ & 0.74 & 0.70 & 0.75 & 0.84 & 0.79 & 0.89 & 0.79 \\
\hline Richness $^{\mathrm{e}}$ & 171.09 & 56.34 & 159.49 & 116.61 & 336.71 & 463.35 & 99.52 \\
\hline Shannon & 4.8 & 3.64 & 4.77 & 5.01 & 5.67 & 6.71 & 4.68 \\
\hline \multirow[t]{2}{*}{ Chao 1} & 788 & 262 & 904 & 487 & 2009 & 2443 & 643 \\
\hline & $(744-852)$ & $(226-327)$ & (816-1026) & $(454-540)$ & $(1880-2170)$ & $(2329-2581)$ & $(543-797)$ \\
\hline Simpson & 0.051 & 0.069 & 0.032 & 0.020 & 0.013 & 0.0029 & 0.018 \\
\hline Index & Sea-Feb & Sea-Apr & Sea-May & Sea-Jun & Sea-Jul & Sea-Aug & Sea-Nov \\
\hline$S^{\mathrm{b}}$ & 606 & 2753 & 1373 & 1085 & 631 & 203 & 215 \\
\hline$N^{\mathrm{c}}$ & 10279 & 21091 & 10051 & 12421 & 3434 & 1218 & 657 \\
\hline Evenness $^{\mathrm{d}}$ & 0.67 & 0.80 & 0.78 & 0.86 & 0.98 & 0.72 & 0.86 \\
\hline Richness $^{\mathrm{e}}$ & 150.80 & 636.43 & 342.81 & 178.18 & 65.46 & 65.46 & 75.95 \\
\hline Shannon & 4.28 & 6.32 & 5.60 & 5.57 & 5.2 & 3.85 & 4.63 \\
\hline \multirow[t]{2}{*}{ Chao 1} & 936 & 4952 & 2650 & 1668 & 1186 & 401 & 469 \\
\hline & (844-1064) & $(4654-5298)$ & $(2413-2940)$ & (1536-1838) & (1041-1384) & $(318-544)$ & $(369-634)$ \\
\hline Simpson & 0.037 & 0.006 & 0.016 & 0.009 & 0.019 & 0.061 & 0.021 \\
\hline
\end{tabular}

${ }^{a}$ Calculations were based on operational taxonomic units (OTUs) formed at an evolutionary distance of $<0.03$ (or $\sim 97 \%$ similarity).

${ }^{\mathrm{b}} S$ defined as the number of OTUs.

${ }^{\mathrm{c}} N$ defined as the number of sequences.

${ }^{\mathrm{d} E v e n n e s s ~ d e f i n e d ~ a s ~ S h a n n o n / L n ~(t h e ~ n u m b e r ~ o f ~ O T U s) . ~}$

${ }^{e}$ Richness $=$ (number of singleton OTUs-1) $/ \log N$. The maximum value is $(N-1) / \log N$.

${ }_{\mathrm{f}}^{\mathrm{f}}$ onfidence intervals for the Chao 1 estimator are shown in parenthesis.

ranged from 0.006 to 0.037 . Student's $t$-test was used to describe the difference between coral and seawater samples. The $P$-value was 0.96 in Shannon's index and 0.94 in Simpson's index. There was no significant difference in Shannon's and Simpson's indices between the coral and seawater samples. In addition, the seasonal tendency of the diversity indices was irregular. Overall, the bacterial communities in both coral and seawater samples were highly diverse.

Composition of I. palifera-associated bacterial community The most abundant bacterial groups in the coral or seawater samples were Alphaproteobacteria (10-50\%) and Gammaproteobacteria (12-50\%); however, the specific composition of each bacterial community in the coral tissues clearly differed from the sea water (Figure 1). There were more bacteria of Betaproteobacteria, Actinobacteria, Acidobacteria and Nitrospira groups in the coral tissues, whereas seawater samples had more bacteria in the Flavobacteria and Cyanobacteria groups (Figure 1).

In our study, high proportions $(5-50 \%)$ of unclassified bacteria were detected in the coral samples using the program SeqMatch from the RDP; in contrast, the seawater samples contained only approximately $5 \%$ unclassified bacteria (Figure 1a). To confirm this observation, we assessed the same data sets using a self-developed method, the GF technique (see Materials and methods). In the coral samples, GF reassigned 32655 unclassi- 


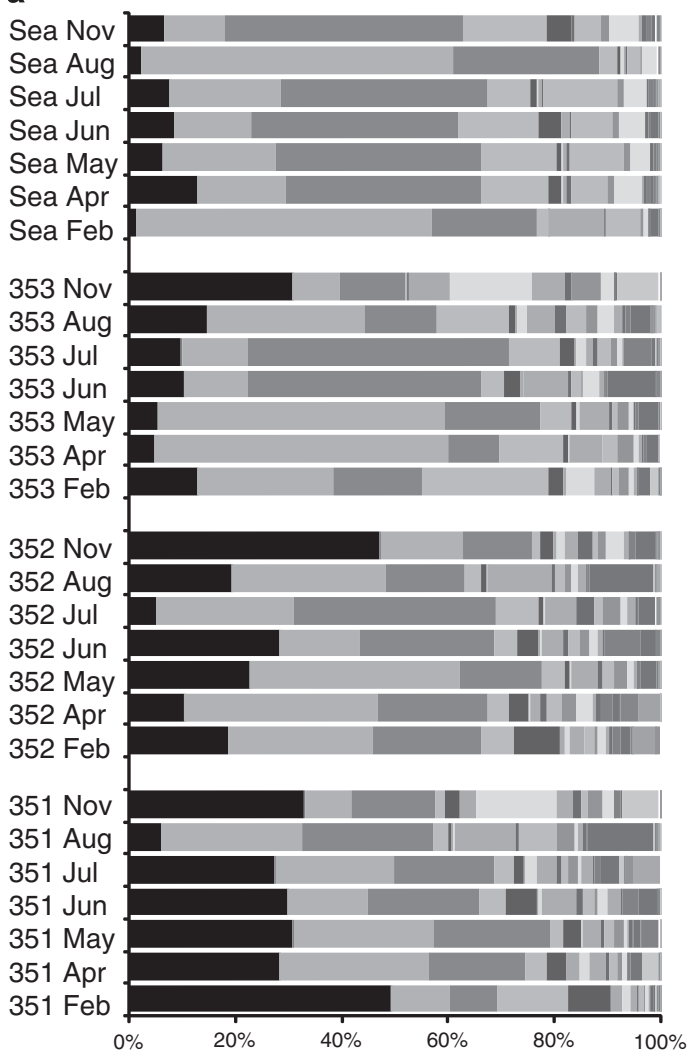

b

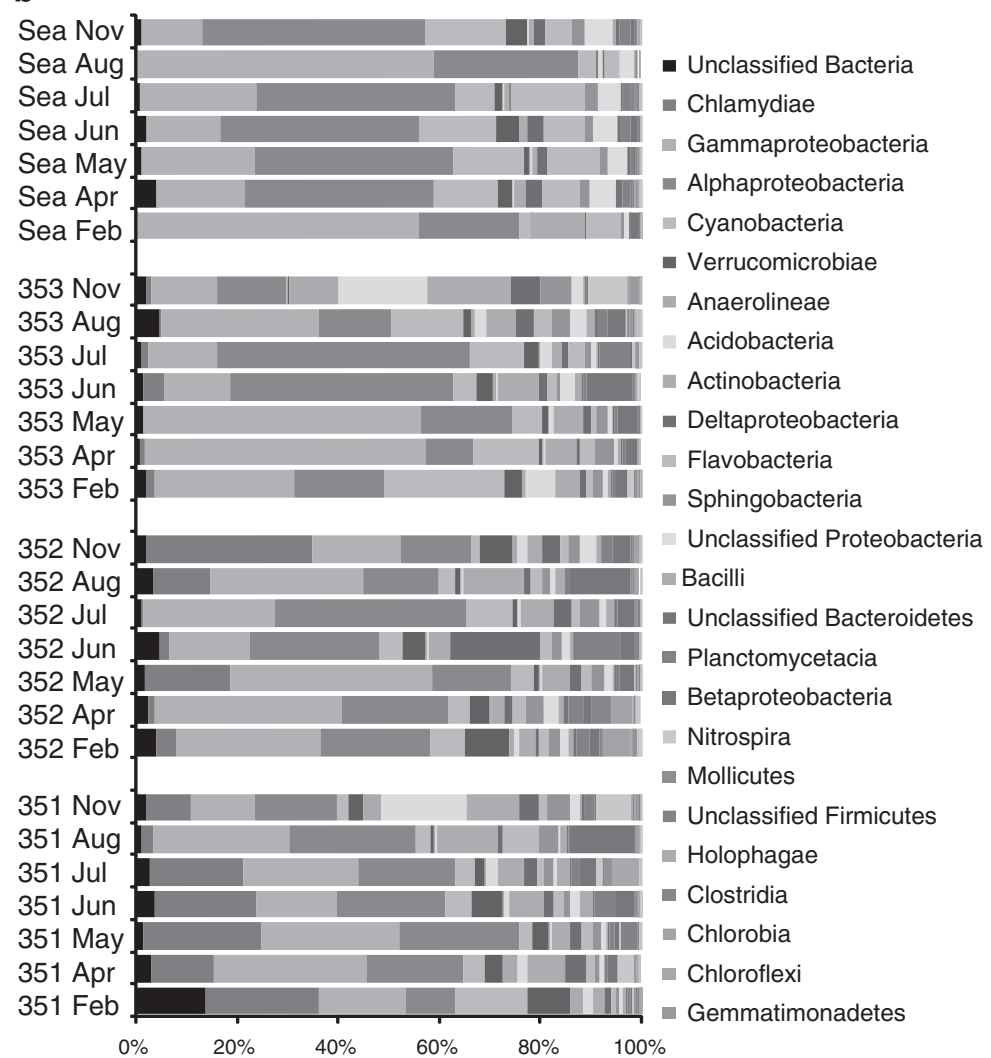

Figure 1 Bacterial composition profile. The bacterial compositions were analyzed using two methods, SeqMatch alone online at RDP (a) and a combination method, SeqMatch-Greedy Fetching (GF) (b). (a) With SeqMatch, high proportions (5-50\%) of unclassified bacteria were detected in the samples. (b) With SeqMatch-GF method, the unclassified bacteria were reduced to $<5 \%$. In these figures, bacteria composition in I. palifera was different from sea water, and the bacterial composition in I. palifera varied in different coral colonies and at different months.

fied sequences in the RDP SeqMatch analysis to different taxonomic classes; in all, 28508 (87\%) unclassified sequences were reassigned to known taxa (Figure 1b). In seawater samples, 4790 sequences were assigned to unclassified bacteria by RDP SeqMatch. After GF analysis, these were reduced to 1174 sequences of unclassified bacteria $(75 \%$ unclassified sequences reassigned to known taxa; Figure 1b).

In addition, by GF refinement, we discovered a group of novel bacteria, which was closely related to Chlamydia (Figures 1a and b). The Chlamydia-like bacteria (CLB; 88\% similarity to Chlamydia based on NCBI database) were specifically found only in the coral samples. This bacterial group was the major population (up to $33 \%$ ) of bacterial communities in the coral samples.

\section{The distribution profile of unique bacterial V6} sequence group

We used the unique V6 sequence group profiles to analyze the bacterial composition below the class level to detect dominant bacteria and their population changes. Overall, most of the bacterial groups in the coral or seawater samples remained minor components of the population most of the time. It was evident, however, that a few particular bacterial groups in the coral samples, such as CLB, Rhodobacteraceae, Sphingomonadales, Escherichia, Pseudomonas and Chroococcidiopsis, largely appear at particular times; however, they became dominant for only brief periods of time (Figure 2). In the seawater samples, SAR11 was the constant predominant group (comprising $3-4 \%$ of total bacteria in most months).

The variation of the composition of bacterial community within each of the coral samples was mainly because of the temporary predominance of a particular bacteria with a considerable population. For instance, the increase of Gammaproteobacteria in April and May (Figure1 and Supplementary Figure S5) was caused by an increase in Escherichia (Figure 2). In colonies 352 and 353, the increase of Alphaproteobacteria in June (Supplementary Figure S5) was caused by an increase in Rhodobacteraceae (Figure 2). In colony 352, the spike of Deltaproteobacteria $(20 \%)$ in June resulted from increasing presence of an unclassified Deltaproteobacterial group. Similarly, the enrichment of Cyanobacteria in February (Figure1 and Supplementary Figure S5) resulted from Chroococcidiopsis (Figure 2). 


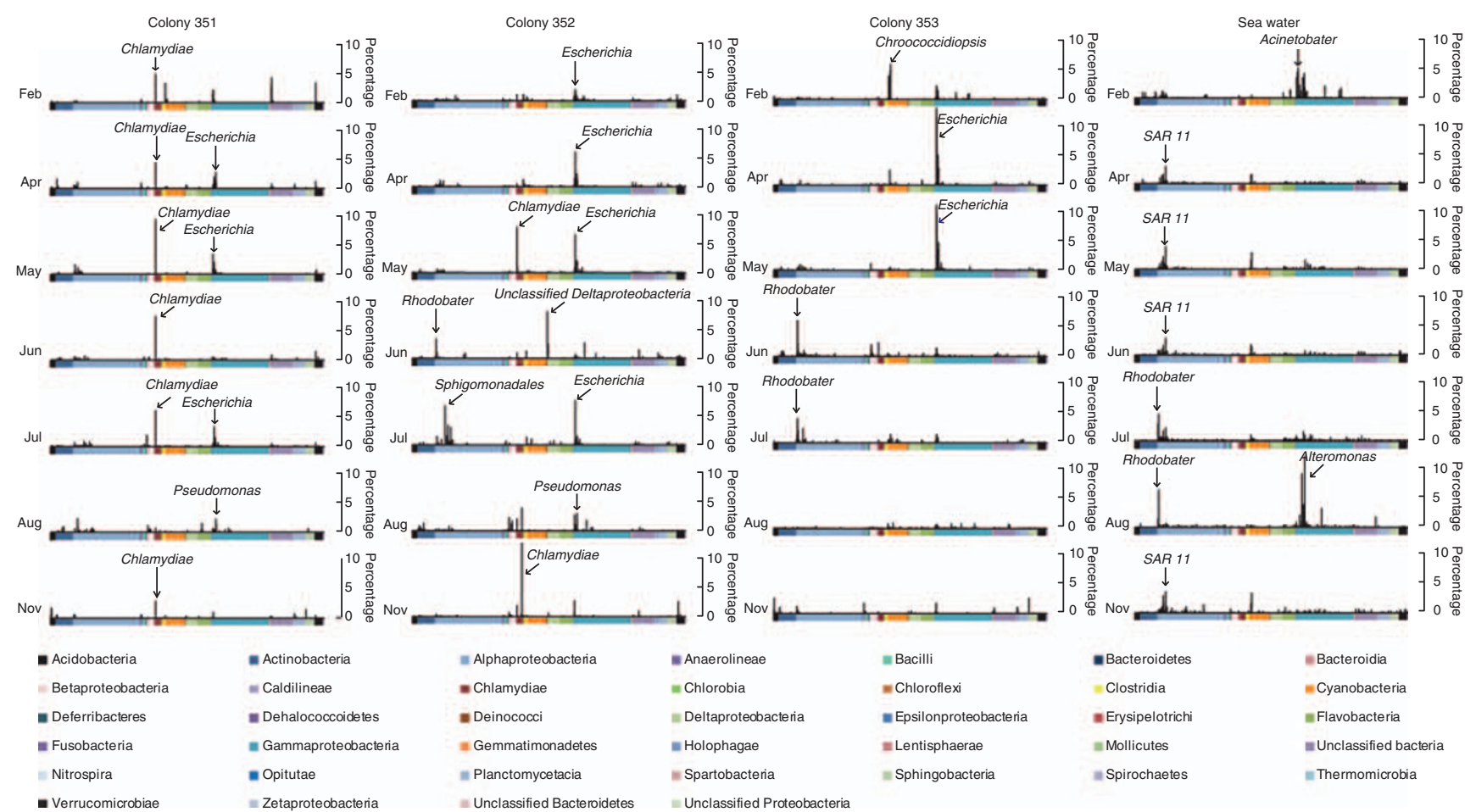

Figure 2 The V6 unique sequence groups in each sample. This profile illustrates dominant bacteria groups and how bacterial communities changed. Variations in the composition of bacterial community within each of the coral samples was rapid and mainly resulted in temporary predominance of bacteria such as Rhodobacteraceae, Sphingomonadales, Escherichia and CLB. The y axis shows the percentage of each unique group in each sample from three colonies and sea water. The color bars on $x$ axis indicate the taxonomy of the bacteria. Each vertical black bar signifies the proportion (\%) of a unique bacterial group (labeled). Some dominant groups could not be defined to Family; therefore, these groups were labeled with class name (such as CLB and Deltaproteobacteria) or cluster name (such as SAR11).

In addition, the distribution profile of unique bacterial V6 sequence groups provided a more detailed resolution of changes in the bacterial community when compared with an analysis of bacterial groups based on higher taxonomic levels (for example, Class; Figure 1). In the seawater samples, Gammaproteobacteria was the major group in February and August; however, the compositions of Gammaproteobacteria in these two months were distinct. Acinetobacter was the most abundant Gammaproteobacterial group in February, but Alteromonas was most abundant in August (Figure 2). Similarly, in colony 352, Gammaproteobacteria was the major group in June and July; however, the compositions of Gammaproteobacteria in these two months were distinct. Rhodobacter was predominant in June, whereas Sphingomonadale predominated in July. CLB was abundant in May and November in colony 352; however, the predominant group of CLB in May was different to that in November. On the contrary, in colony 351, the predominant groups of CLB remained the same in all months.

\section{Comparison of I. palifera-associated bacterial} communities

Based on sequence similarity, a total of 11236 OTUs were classified by DOTUR using the Juke-Cantor model with a cutoff value of $3 \%$. The OTU percentages in each sample were incorporated into the nMDS matrix and analyzed by city-block distance. The coral-associated bacterial communities were relatively closer to each other and significantly different from the bacterial community of the sea water in the two-dimensional nMDS map, which also supports the result of the analysis of the bacterial taxonomy (Figure 3).

In addition, the bacterial communities of the coral samples collected in the same month clustered together closely (Figure 3). The bacterial compositions of the samples of spring and summer were more similar to each other, whereas the winter samples also congregated together.

\section{Symbiodinium communities}

Two methods, PCR-LH and Q-PCR, were adopted to quantify the population of Symbiodinium clades C and D (symbiotic algae). Initially, we adopted the PCR-LH technique to detect the population proportions of two Symbiodinium clades. Two distinguishable specific PCR products (102 and $96 \mathrm{bp}$ ) of ITS2 region of clades $\mathrm{C}$ or $\mathrm{D}$ were analyzed using ureapolyacrylamide gel electrophoresis (Supplementary Figure S7a). The relative proportions of these two populations in the coral samples were determined by band intensity. The histogram shows the profile 


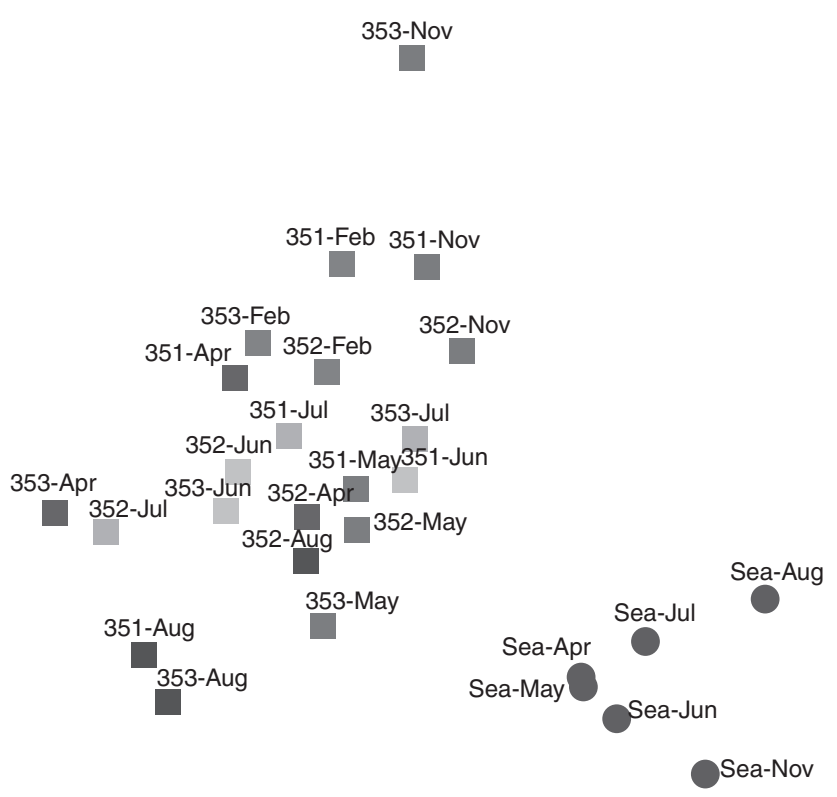

Sea-Feb

Figure 3 Non-metric multidimensional scaling ordination (nMDS) analysis. We used the relative percentages of each OTU (at $3 \%$ cutoff value) in each sample to perform nMDS mapping (see Materials and methods). In this map, each dot signifies the bacterial population of an individual sample. The square boxes show coral samples, and blue circles show seawater samples. In the coral samples, different colors represent different months. The coral-associated bacterial communities were relatively close to each other and significantly different from the bacterial community of the sea water. Moreover, the bacterial compositions of the coral samples collected in the same month tended to cluster together. The color reproduction of this figure is available on the html full text version of the manuscript.

of the C/D ratio in the different coral samples and months (Supplementary Figure S7b). In colony 351, clade D was the constant predominant group in all the samples, and the symbiotic algal communities were more stable than those in colonies 352 and 353.

Using specific primers based on the indel mutation region in ITS1 of clades C and D, we performed three independent Q-PCRs to confirm the result of PCR-LH. The Q-PCR results (Figure 4) were similar to those from PCR-LH (Supplementary Figure S7). However, inaccuracy of the relative ratio of clades $C$ and D occurred when using PCR-LH because that technique failed to represent the correct measured value if the band's color intensity exceeded the saturation threshold, and the proportion of an abundant group was therefore underestimated. For instance, in $351-\mathrm{Feb}$, the clade $\mathrm{D}$ proportion was estimated at $\sim 80 \%$ and $99 \%$ in PCR-LH and Q-PCR analysis, respectively. On the other hand, in 352-Apr, the clade $\mathrm{C}$ proportion was estimated to be $60 \%$ in PCR-LH but $80 \%$ in Q-PCR.

According to the results of Q-PCR and PCR-LH, all coral colonies contained both clades $\mathrm{C}$ and $\mathrm{D}$
(Figure 4 and Supplementary Figure S7). In April, there was a sharp increase in the clade $\mathrm{C}$ population ( $>60 \%$ proportion) in colonies 352 and 353 . However, the Symbiodinium spp. population of colony 351 was dominated by clade D (>98\% proportion) throughout our survey (Figure 4). Take together, these results show that Symbiodinium composition in I. palifera varied at different times and that the extent of this effect varied in different colonies.

\section{Hierarchical clustering analysis}

We used hierarchical clustering analysis to examine the relationships between environmental factors (seawater temperature, sunlight intensity and rainfall), bacterial community and symbiotic algal population. The proportion of Clostridia reached a maximum in April, whereas proportions of Chlorobia and Chloroflexi were high in February and April. Rainfall and the population of Bacilli had a similar profile (Figure 5), which supported the association of a high Bacilli proportion with rainfall (Supplementary Figure S8). There were no associations between seawater temperature or sunlight intensity and the variation of various bacterial groups at the class level (Figure 5). The proportion of Symbiodinium clade C increased in April, whereas the clade $\mathrm{D}$ proportion decreased at the same time. The changes in Symbiodinium proportion were not similar to the variation of bacterial groups at the class level (Figure 5).

\section{Discussion}

In this study, we suggest that both bacterial and Symbiodinium populations in the coral I. palifera vary at different times and to different extents in different colonies; notably, the compositional changes of bacterial community are likely to be associated with seasonal changes. The extensive information provided by the recently developed technique of MPP clearly defines monthly changes of the coral-associated bacterial community that were unavailable in previous surveys using older methods or shorter sampling timescales (Rohwer et al., 2002; Koren and Rosenberg, 2006; Hong et al., 2009).

Factors affecting fluctuation of the I. palifera-associated bacterial community

Our results suggest that three factors affected the coral-associated bacterial community, including the environment (rainfall) (Figure 5 and Supplementary Figure S8), seasonal changes (Figure 3) and colony variation (Figures 1 and 2).

Environmental factors were considerable drivers of the structure of the coral-associated bacterial community, as also suggested by other studies (Koren and Rosenberg, 2006; Garren et al., 2009; Hong et al., 2009; Littman et al., 2009). Three factors 


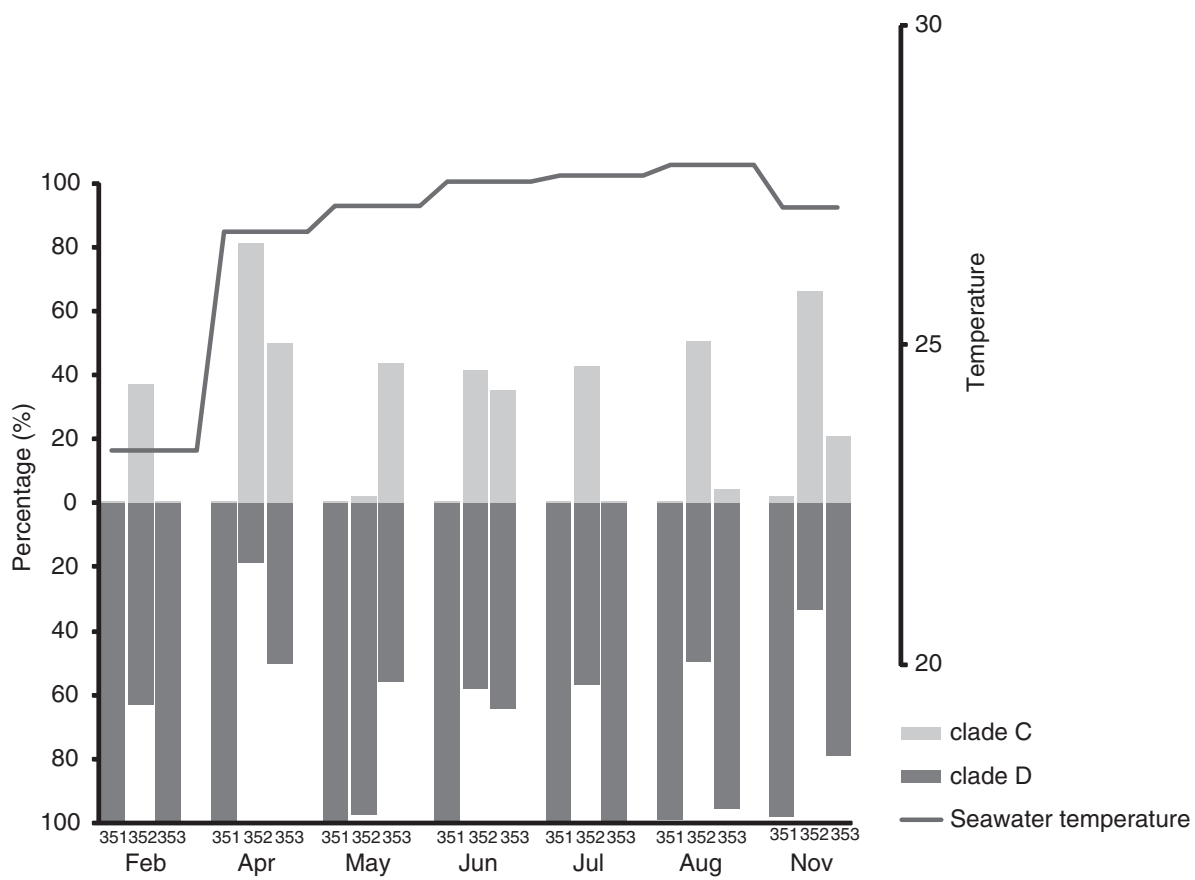

Figure 4 Symbiodinium population analysis by real-time quantitative-PCR. Two populations of Symbiodinium clades C and D were determined by real-time quantitative PCR of the ITS. All the coral colonies contained both clades C and D but the relative proportion of the Symbiodinium members varied at different times and between coral colonies. In April, the temperature shifting point, there was a sharp increase in the clade C population ( $>60 \%$ proportion) in colonies 352 and 353 . However, the Symbiodinium spp. population of colony 351 was dominated by clade $\mathrm{D}$ ( $>98 \%$ proportion) throughout our survey. The green bar is the proportion of clade $\mathrm{C}$ and the blue bar is the proportion of clade $\mathrm{D}$. The right $y$ axis is percentage and the left $y$ axis is temperature $\left({ }^{\circ} \mathrm{C}\right)$. The color reproduction of this figure is available on the html full text version of the manuscript.

(seawater temperature, sunlight intensity and rainfall) were available and included in this study in the association analysis with the bacterial groups. Among these environmental factors, rainfall seems to be the factor with greatest effect on the bacterial community of I. palifera at Ken-Ting. Changes in the pattern of Bacilli bacteria were associated with rainfall (Figure 5 and Supplementary Figure S8). This bacterial group comprised $1 \%$ of the total bacterial community in the coral, and many Bacili are soil-borne bacteria. We speculate that these bacteria might come from terrestrial soil because in the summer months (from June to August), abundant rainfall $(\sim 500 \mathrm{~mm}$ per month; Supplementary Figure S9) flushed out a great amount of soil from the land to the coastal waters around Ken-Ting (Meng et al., 2008). Soil-borne bacteria, such as Bacilli, were likely disseminated to the reef where they took up brief residence in coral. A similar phenomenon has also been detected and discussed in another report (Hong et al., 2009), but there has been no other direct evidence.

Based on the cluster analysis, unlike the rainfall effect on coral-associated bacteria (Figure 5), there was no association between seawater temperatures and bacterial group variation (Figure 5). The water temperature in Ken-Ting changed over a small range $\left(24-28{ }^{\circ} \mathrm{C}\right.$ ) during our study (Supplementary Figure S9). This result suggests that water temperature might not be a decisive factor triggering the compositional change of bacterial community in I. palifera at Ken-Ting. Perhaps, larger temperature changes might have more effect, or other unknown environmental factors that still require further investigation may be involved.

Seasonal variation was another potential factor prompting compositional change of the bacterial communities. In the nMDS analysis, the bacterial composition profiles of the coral samples collected in the same month tended to cluster together (Figure 3). Moreover, the bacterial compositions of the samples of spring (April and May) and summer (June, July and August) were similar to each other, and the samples of winter (February and November) clustered separately (Figure 3), similar to our cluster analysis (data not shown). The composition of the I. palifera-associated bacterial community had seasonal-dependent variation. Apart from water temperature, other environmental conditions accompanying seasonal changes may have caused the bacterial composition to alter significantly. To confirm seasonal changes or temporal dynamics on the coral-associated bacterial community, a longer survey and a larger sample size should be able to provide more information.

Alphaproteobacteria and Gammaproteobacteria were the two constant predominant groups in I. palifera, as seen in previous observations on the 

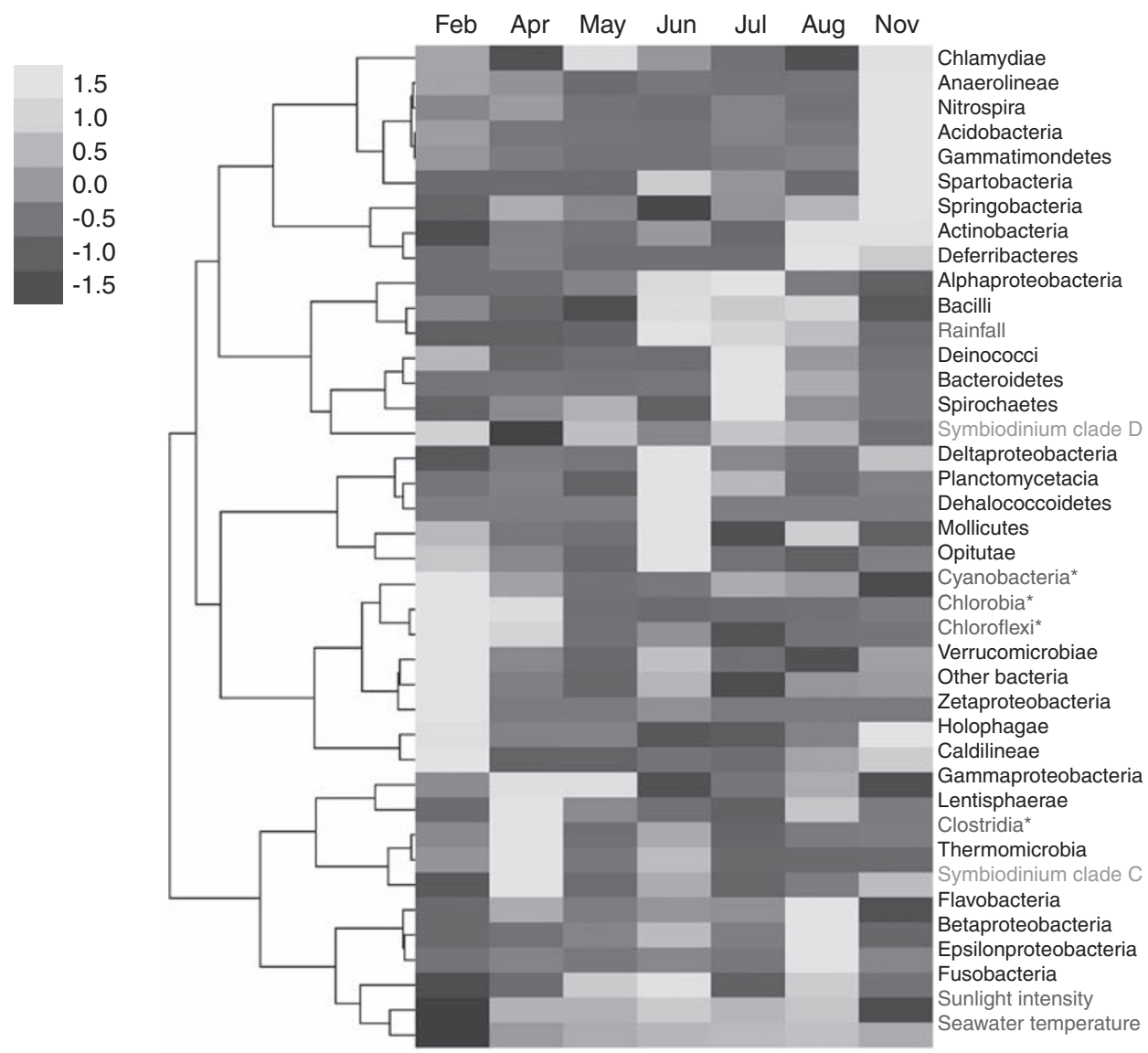

Figure 5 Hierarchical cluster analysis. Single-way clustering method was used to dissect relationships between the abundance of 35 individual bacterial groups at class level, the abundance of Symbiodinium (containing both clades C and D) and environmental parameters (seawater temperature, sunlight intensity and rainfall) in the seven months of February, April, May, June, July, August and November. Lighter colors (yellow) mean more members of the bacterial and Symbiodinium group detected, or higher values of environmental conditions. Darker colors (dark blue) mean fewer bacteria or Symbiodinium or lower values of environmental conditions. In this map, rainfall and population of Bacilli were correlated. Potential nitrogen fixation bacteria (Cyanobacteria, Clostridia, Chlorobia and Chloroflexi) were enriched in February and April. The proportion of symbiont clade $\mathrm{C}$ was increased in April. Heat map intensities were calculated from normalized data (see Materials and methods) with the uncentered correlation distance and complete linkage, the two options in the Gene Cluster 3.0. Blue: potential nitrogen fixation bacteria, labeled by *. Red: environmental factors, seawater temperature, sunlight intensity and rainfall. Orange: the Symbiodinium clades. The color reproduction of this figure is available on the html full text version of the manuscript.

coral Acropora (a coral genus closely related to Isopora) in the Great Barrier Reef (Hong et al., 2009; Littman et al., 2009). Both of these bacterial groups comprised $>10 \%$ proportions of the bacterial communities in Acropora and I. palifera. Importantly, however, CLB were abundant (up to $33 \%$ ) in I. palifera, but were not detected in Great Barrier Reef Acropora (Littman et al., 2009). This difference might be caused by differences in geography and coral species, or they may have been present but were undetected by previous methods.

Escherichia and Rhodobacteraceae were the major groups, respectively, of the Alphaproteobacteria and Gammaproteobacteria detected in I. palifera. Escherichia, the dominant group in April and May (Figure 2), appeared consistently in all colonies. In addition, Escherichia was assumed to be an animalassociated bacteria (Feng et al., 2002). Escherichia presence may be indicative of human and animal waste, because the coast of Ken-Ting is a popular tourist spot. However, the exact reason for the appearance of Escherichia still needs more evidence to prove conclusively. Rhodobacteraceae, a group of photosynthetic bacteria (Paoli and Tabita, 1998; Xiong et al., 2000), appeared abundantly in colonies 352 and 353 in June (Figure 2). Potential functions of this particular group in corals have not been described. Notably, June brought together relatively high levels of rainfall, temperature and sunlight, as indicated in the clustering analysis. Is this appearance of Rhodobacteraceae associated with these environmental factors? The answer is still uncertain.

The cyanobacteria Chroococcidiopsis was abundant in colony 353 in February (Figure 2). Chroococcidiopsis has been found on the rock in marine environments (Díez et al., 2007; Goh et al., 2009). However, the reason for its appearance in coral is still unknown. 
Diversity of the coral-associated bacteria is very high In this study with a large survey ( $>200000$ reads using pyrosequencing), we have shown that the bacterial communities in sea water and coral are highly diverse, with Shannon's index as high as 6.71, much higher than the 4.95 found using the clone library method (reviewed in Reshef et al., 2006). This is the highest index value of diversity ever detected in a coral-associated bacterial community. Despite the difference between the two methods of measuring the index value, our result suggests that the diversity of the coral-associated bacteria is much higher than previously thought. Moreover, our study also highlights that the survey number of a representative gene, such as the $16 \mathrm{~S}$ ribosomal RNA gene, is critical in revealing the composition of a bacterial community. The rarefaction curves (at a $3 \%$ cutoff value) of the samples show that the sampling size (read number) in our survey, with over 1500 sequences for each coral sample (Table 1), was sufficient to reveal the bacterial community in I. palifera (Supplementary Figure S4).

\section{Potential nitrogen fixer groups}

Corals can take up ammonium and nitrate compounds from surrounding water as a nitrogen source (Grover, 2002, 2003). However, as the reef ecosystem is a nutrient-limited environment (Muscatine and Porter, 1977), bacteria-driven nitrogen fixation can compensate for any deficiency of nitrogen source for coral holobiont (Shashar et al., 1994; Lesser et al., 2004). Nitrogen-fixing bacteria have been detected elsewhere in coral (Shashar et al., 1994; Lesser et al., 2004). In this study, we also detected several potential nitrogen fixers, including Cyanobacteria (Meeks, 1998; Berman-Frank et al., 2003), Clostridia (Chen et al., 2001), Chlorobia (Wahlund and Madigan, 1993) and Chloroflexi (Seshadri et al., 2005; Kneip et al., 2007). These potential nitrogen fixer groups in I. palifera greatly were enriched in February and April (Figure 5). Although better evidence is still lacking, we speculate that this phenomenon might be caused by a relative nitrogen limitation from February to April (Meng et al., 2008). During this period, the coral might be able to acquire some nitrogen from these potential nitrogen fixers. However, in the summer (June, July and August), the nitrogen-limited condition was released by abundant rainfall flushing a large amount of nutrients, including nitrogen sources, into coastal waters from river outflow as previously observed (Meng et al., 2008), and the potential bacterial nitrogen fixer population proportion also decreased.

The fluctuation of the symbiotic algal composition The composition of Symbiodinium in corals is known to be changeable (Toller et al., 2001; LaJeunesse et al., 2004; Chen et al., 2005; Reimer et al., 2007), varying with environmental conditions such as season (Chen et al., 2005), latitude (LaJeunesse et al., 2004) and depth (Toller et al., 2001; Frade et al., 2008). We also observed changes in the algal symbiont population in terms of number and composition. According to our PCR heteroplasmy and Q-PCR analyses, the algal symbiont composition in the coral samples continuously fluctuated but both clades $\mathrm{C}$ and $\mathrm{D}$ were always detectable in all three tagged colonies throughout our survey.

What drives the change of dominance of the algal population? The relevant factors are probably highly complex. One factor may be the difference in physiological properties between the two clades (Rowen, 2004). Most of Symbiodinium clade D is heat tolerant and they are commonly found in corals living in shallow and inshore reefs with more radiation and higher temperature fluctuation (Baker, 2003; Rowen, 2004; LaJeunesse et al., 2008). Thus, harboring symbionts of clade D may increase the survival rate of the coral during bleaching events in hot seasons as suggested by Jones et al. (2008). However, clade D may not be the perfect symbiotic partner all the time. In juvenile coral stages, corals infected with clade $\mathrm{D}$ grew slower than those with clade C (Little et al., 2004), suggesting that members of clade $\mathrm{C}$ may provide other growth benefits than clade D algae despite their greater temperature sensitivity (Rowen, 2004). It should also be noted that not all subgroups of clade D confer temperature tolerance in corals (Abrego et al., 2008). Considering the complexity of physiological features in clades $\mathrm{C}$ and $\mathrm{D}$, we suggest that a better analysis of each major subgroup of clades C and D may shed more light on their population dynamics during season changes. Although the reasons for the seasonal alterations in clade proportion are still unclear, these changes occurred internally in the coral because we did not detect any of the algal genes in the seawater samples (data not shown).

Issues for use of nucleotide-tag primers in MPP MPP offers several advantages to surveys of microbial communities, including sufficient data, low cost, low labor requirements and avoidance of bias (Sogin et al., 2006; Binladen et al., 2007; Huse et al., 2008). However, when amplifying the 16S rRNA gene using universal bacterial primers with specific tag sequences, it has been argued that appending different tag sequences to the universal primers would bring extra bias during the amplification by PCR because of the differential hybridization efficiency of different primers. Similarly, we have also observed a similar problem in that universal primers with different code sequences may be a cause of differential amplification efficiency. To avoid such bias from different code sequences, we first amplified the bacterial V6 region with universal bacterial primers without tag sequences, and only then carried out DNA tagging PCR with a very low number of amplification cycles, a process that can specifically 
add individual code sequences to different PCR amplicons with universal bacterial primers containing different code sequences. Compared with the previous method, this newly modified technique for DNA coding generates less artificial bias.

We strongly recommend the MPP approach for the study of the population dynamics of microbial patterns in coral because of the highly dynamic nature of such populations in response to temporal or seasonal factors and the evident variation among individual colonies in corals, such as I. palifera. The robustness of the technique can provide the capacity to handle a large number of samples with affordable costs and low labor requirements (Sogin et al., 2006; Binladen et al., 2007; Huse et al., 2008).

\section{Acknowledgements}

We thank Garmin Hsu and the colleagues of Allen CL Chen for assistance with providing samples and seawater temperature data. This study was supported by thematic project funding of Academia Sinica, Taiwan, and by the Biodiversity Research Center, Academia Sinica, Taiwan.

\section{References}

Abrego D, Ulstrup KE, Willis BL, van Oppen MJH. (2008). Species-specific interactions between algal endosymbionts and coral hosts define their bleaching response to heat and light stress. Proc $R$ Soc $B$ 275: 2273-2282.

Acinas SG, Klepac-Ceraj V, Hunt DE, Pharino C, Ceraj I, Distel DL et al. (2004). Fine-scale phylogenetic architecture of a complex bacteria community. Nature 430: $551-554$.

Amann RI, Ludwig W, Schleifer KH. (1995). Phylogenetic identification and in situ detection of individual cells without cultivation. Microbiol Rev 59: 143-169.

Andersson AF, Riemann L, Bertilsson S. (2010). Pyrosequencing reveals contrasting seasonal dynamics of taxa within Baltic Sea bacterioplankton communities. ISME J 4: 171-181.

Baker AC. (2001). Reef corals bleach to survive change. Nature 411: 765-766.

Baker AC. (2003). Flexibility and specificity in coral algal symbiosis: diversity, ecology, and biogeography of Symbiodinium. Annu Rev Evol Syst 34: 661-689.

Barriuso J, Marin S, Mellado RP. (2010). Effect of the herbicide glyphosate on glyphosate-tolerant maize rhizobacterial communities: a comparison with preemergency applied herbicide consisting of a combination of acetochlor and terbutylazine. Environ Microbiol 12: 1021-1030.

Berman-Frank I, Lundgern P, Falkowski P. (2003). Nitrogen fixation and photosynthetic oxygen evolution in cyanobacteria. Res Microbiol 154: 157-164.

Binladen J, Gilbert MTP, Bollback JP, Panitz F, Bendixen C, Nielsen R et al. (2007). The use of coded PCR primers enables high-throughput sequencing of multiple homolog amplification products by 454 parallel sequencing. PLoS ONE 2: e197.

Chen CA, Wang JT, Fang LS, Yang YW. (2005). Fluctuating algal symbiont communities in Acropora palifera (Scleractinia: Acroporidae) from Taiwan. Mar Ecol Prog Ser 295: 113-121.

Chen JS, Toth J, Kasap M. (2001). Nitrogen-fixation genes and nitrogenase activity in Clostridium acetobutylicum and Clostridium beijerinckii. J Ind Microbiol Biotechnol 27: 281-286.

de Hoon MJL, Imoto S, Nolan J, Miyano S. (2004). Open source clustering software. Bioinformatics 20: 1453-1454.

Díez B, Bauer K, Bergman B. (2007). Epilithic cyanobacterial communities of a marine tropical beach rock (Heron Island, Great Barrier Reef): diversity and diazotrophy. Appl Environ Microbiol 73: 3656-3668.

Feng P, Weagant S, Grant M. (2002). Enumeration of Escherichia coli and the coliform bacteria. In: Merker RI (ed.). Bacteriological Analytical Manual, 8th edn., revision A. U.S. Food and Drug Administration: College Park, MD.

Frade PR, Jongh FDE, Vermeulen F, Bleijswijk JV, Bak RPM. (2008). Variation in symbiont distribution between closely related coral species over large depth ranges. Mol Ecol 17: 691-703.

Garren M, Raymoundo L, Guest J, Harvell CD, Azam F. (2009). Resilience of coral associated bacterial communities exposed to fish farm effluent. PLoS ONE 4: e7391.

Goh F, Michelle AA, Leuko S, Kawaguchi T, Decho AW, Burns BP et al. (2009). Determining the specific microbial populations and their spatial distribution within the stromatolite ecosystem of Shark Bay. ISME J 3: 383-396.

Grover R. (2002). Uptake of ammonium by the scleractinian coral Stylophora pistillata: effect of feeding light, and ammonium concentrations. Limnol Oceanogr 47: $782-790$.

Grover R. (2003). Nitrate uptake in the scleractinian coral Stylophora pistillata. Limnol Oceanogr 48: 2266-2274.

Hong MJ, Yu YT, Chen ACL, Chiang PW, Tang SL. (2009). Influence of species specificity and other factors on bacteria associated with Stylophora pistillata in Taiwan. Appl Environ Microbiol 75: 7797-7806.

Huber JA, Welch DBM, Morrison HG, Huse SM, Neal PR, Butterfield DA et al. (2007). Microbial population structures in the deep marine biosphere. Science 318: 97-100.

Huse SM, Dethlefsen L, Huber JA, Welch DM, Relman DA, Sogin ML. (2008). Exploring microbial diversity and taxonomy using SSU rRNA hypervariable tag sequencing. PLOS ONE 4: e1000255.

Jones AM, Berkelmans R, van Oppen MJH, Mieog JC, Sinclair W. (2008). A community change in the algal endosymbionts of coral following a natural bleaching event: field evidence of acclimatization. Proc $R$ Soc $B$ 275: 1359-1365.

Kenkel NC, Orlóci L. (1986). Applying metric and nonmetric multidimensional scaling to ecological studies: some new results. Ecology 67: 919-928.

Klaus JS, Janse I, Heikoop JM, Sanford RA, Fouke BW. (2007). Coral microbial communities, zooxanthellae and mucus along gradients of seawater depth and coastal pollution. Environ Microbiol 9: 1291-1305. 
Kneip C, Lockhart P, Voß C, Maier U-G. (2007). Nitrogen fixation in eukaryotes: new models for symbiosis. BMC Evol Biol 7: 55.

Knowlton N, Rohwer F. (2003). Multispecies microbial mutualisms on coral reefs: the host as a holobiont. Am Nat 162: S51-S62.

Koren O, Rosenberg E. (2006). Bacteria associated with mucus and tissues of the coral Oculina patagonica in summer and winter. Appl Environ Microbiol 72: 5254-5259.

Lajeunesse TC, Bhagooli R, Hidaka M, de Vantier L, Done T, Schmidt GW et al. (2004). Closely related Symbiodinium spp. differ in relative dominance in coral reef host communities across environmental, latitudinal and biogeographic gradients. Mar Ecol Prog Ser 284: 147-161.

Lajeunesse TC, Bonilla HR, Warner ME, Willis M, Schmidt GW, Fitt WK. (2008). Specificity and stability in high latitude eastern Pacific coral-algal symbioses. Limnol Oceanogr 53: 719-727.

Lampert Y, Kelman D, Nitzan Y, Dubinsky Z, Behar A, Hill RT. (2008). Phylogenetic diversity of bacteria associated with the mucus of red sea corals. FEMS Microbiol Ecol 64: 187-198.

Lesser MP, Mazel CH, Gorbunov MY, Falkowski PG. (2004). Discovery of symbiotic nitrogen fixing cyanobacteria in coral. Science 305: 997-1000.

Little AF, van Oppen MJH, Willis B. (2004). Flexibility in algal endosymbioses shapes growth in reef corals. Science 304: 1492-1494.

Littman RA, Willis BL, Pfeffer C, Bourne DG. (2009). Diversity of coral associated bacteria differ with location, but not species, for three acroporid corals on the Great Barrier Reef. FEMS Microbiol Ecol 68: 152-163.

Marhaver KL, Edwards RA, Rohwer F. (2008). Viral communities associated with healthy and bleaching corals. Environ Microbiol 10: 2277-2286.

Meeks JC. (1998). Symbiosis between nitrogen-fixing cyanobacteria and plants. BioScience 48: 266-276.

Meng PJ, Lee HJ, Wang JT, Chen CC, Lin HJ, Tew KS et al. (2008). A long-term survey on anthropogenic impacts to the water quality of coral reefs, southern Taiwan. Environ Pollut 156: 67-75.

Mieog JC, Olsen JL, Berkelmans R, Bleuler-Martinez SA, Willis BL, van Oppen MJ. (2009). The roles and interactions of symbionts, host, and environment in defining coral fitness. PLOS ONE 4: e6364.

Muscatine L, Porter JW. (1977). Reef corals: mutualistic symbioses adapted to nutrient-poor environment. Bioscience 27: 454-460.

Paoli GC, Tabita FR. (1998). Aerobic chemolithoautotrophic growth and RubisCO function in Rhodobacter capsulatus and a spontaneous gain of function mutant of Rhodobacter sphaeroides. Arch Microbial 170: 8-17.

Reimer JD, Ono S, Tsukahrara J, Takishita K, Maruyama T. (2007). Non-seasonal clade-specificity and subclade microvariation in symbiotic dinoflagellates (Symbiodinium spp.) in Zoanthus sansibaricus (Anthozoa: Hexacorallia) at Kagoshima Bay, Japan. Phycological Res 55: 58-65.
Reis AMM, Araújo Jr SD, Moura RL, Francini-Filho RB, Pappas Jr G, Coelho AMA et al. (2009). Bacterial diversity associated with the Brazilian endemic reef coral Mussismilia. J Appl Microbiol 106: 1378-1387.

Reshef L, Koren O, Loya Y, Zilber-Rosenberg I, Rosenberg E. (2006). The coral probiotic hypothesis. Environ Microbiol 8: 2068-2073.

Roesch LFW, Fulthorpe RR, Rive A, Casella G, Hadwin AKM, Kent $\mathrm{AD}$ et al. (2007). Pyrosequencing enumerates and contrasts soil microbial diversity. ISME J 1: 283-290.

Rohwer F, Seguritan V, Azam F, Knowlton N. (2002). Diversity and distribution of coral-associated bacteria. Mar Ecol Prog Ser 243: 1-10.

Rosenberg E, Koren O, Reshef L, Efrony R, ZilberRosenberg I. (2007). The role of microorganisms in coral health, disease and evolution. Nat Rev Microbiol 5: $355-362$.

Rowen R. (2004). Thermal adaptation in reef coral symbionts. Nature 430: 742 .

Sambrook J, Russell DW. (2001). Recovery of DNA from agarose and polyacrylamide gels: electroelution into dialysis bags. Molecular Cloning. CSHL Press: Cold Spring Harbor, NY. vol. 1, pp 5.23-5.25.

Schloss PD, Handelsman J. (2005). Introducing DOTUR, a computer program for defining operational taxonomic unit and estimating species richness. Appl Environ Microbiol 71: 1501-1506.

Seshadri R, Adrian L, Fouts DE, Eisen JA, Phillippy AM, Methe BA et al. (2005). Genome sequence of the PCEdechlorinating bacterium Dehalococcoides ethenogenes. Science 307: 105-108.

Shashar N, Cohen Y, Loya Y, Sar N. (1994). Nitrogen fixation (acetylene reduction) in stony corals: evidence for coral-bacteria interactions. Mar Ecol Prog Ser 111: 259-264.

Sogin ML, Morrison HG, Huber JA, Welch DM, Huse SM, Neal PR et al. (2006). Microbial diversity in the deep sea and the underexplored 'rare biosphere'. Proc Natl Acad Sci USA 103: 12115-12120.

Stat M, Morris E, Gates RD. (2008). Functional diversity in coral-dinoflagellate symbiosis. Proc Natl Acad Sci USA 105: 9256-9261.

Takahashi S, Whitney SM, Badger MR. (2009). Different thermal sensitivity of the repair of photodamaged photosynthetic machinery in cultured Symbiodinium species. Proc Natl Acad Sci USA 106: 3237-3242.

Toller WW, Rowan R, Knowlton N. (2001). Zooxanthellae of the Montastraea annularis species complex: patterns of distribution of four taxa of Symbiodinium on different reefs and across depths. Biol Bull 201: 348-359.

Wahlund TM, Madigan MT. (1993). Nitrogen-fixation by the thermophilic green sulfur bacterium chlorobiumtepidum. J Bacteriol 175: 474-478.

Wegley L, Edwards R, Rodriguez-Brito B, Liu H, Rohwer F. (2007). Metagenomic analysis of the microbial community associated with the coral Porites astreoides. Environ Microbiol 9: 2707-2719.

Xiong J, Fischer WM, Inoue K, Nakahara M, Bauer CE. (2000). Molecular evidence for the early evolution of photosynthesis. Science 289: 1724-1730.

Supplementary Information accompanies the paper on The ISME Journal website (http://www.nature.com/ismej) 